\title{
Proctor Plumbing Limited: A Case Study Of The Balanced Scorecard (BSC)
}

Yvonne P. Shanahan, (Email: yvonne.shanahan@.canterbury.ac.nz), University of Canterbury, New Zealand

\begin{abstract}
This paper presents a teaching case study on the balanced scorecard (BSC) for a plumbing firm. The case requires participants to apply BSC principles by producing a wall poster illustration of the BSC. The participants are then required to take a gallery tour of the wall poster illustrations, share their experiences and assess the illustrations for both content and presentation. The case is applicable in introductory and advanced management accounting courses.
\end{abstract}

\section{THE BALANCED SCORECARD: BRIEF LITERATURE REVIEW}

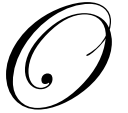

ne of the most influential methods of non-financial performance measurement has been the Balanced Scorecard (BSC). The BSC is now well-established as a performance measurement device. It is a management approach that can lead a company or business unit to focus on achieving current financial results as well as creating future value through strategic activities. Kaplan and Norton (2001a, 2001b) argue that senior managers need this balanced approach because reliance on financial measures alone cannot motivate, predict or create future performance.

The BSC tracks performance from four perspectives as shown in Figure One on the next page.

Each of the four perspectives aims at asking the following questions:

- $\quad$ Financial: How do we look to shareholders?

- $\quad$ Customers: How do customers see us?

- Internal processes: What must we excel at?

- Innovation and learning: Can we continue to improve and create value?

The BSC facilitates activities with value-adding potential, such as:

- $\quad$ Making strategy operational by translating strategy into action.

- $\quad$ Focussing the entire organisation on what must be done to create breakthrough performance.

- Acting as an integrating device, an umbrella, for a variety of diverse, often disconnected corporate programmes such as quality, re-engineering, process redesign, and customer service.

- $\quad$ Translating corporate level measures into measures at lower levels in the organisation so that local managers, operators, and employees can see what they must do well in order to improve organisational effectiveness.

- $\quad$ Providing a comprehensive view that overturns the traditional idea of the organisation as a collection of isolated, independent functions and departments. 
Figure One: The Balanced Scorecard (Examples Of Measures): Adapted From Kaplan And Norton (1992) - Source Blundell Et Al (2003), P.52.

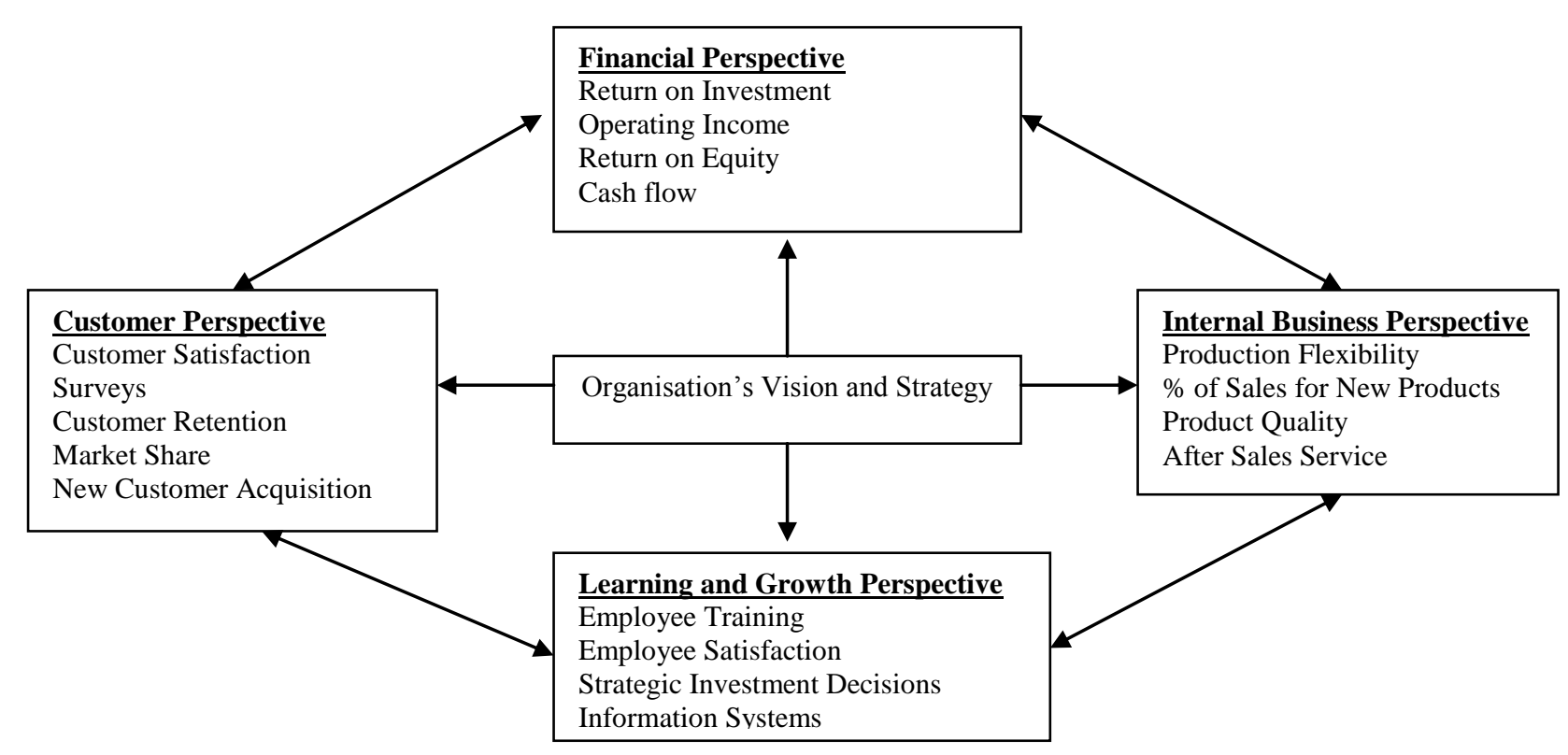

\section{PROCTOR PLUMBING LIMITED ${ }^{1}$ : A CASE STUDY ON THE BALANCED SCORECARD}

The purpose of this case study is to design a BSC, with goals and measures for a plumbing company, called Proctor Plumbing Limited.

The learning outcomes are:

- $\quad$ To apply BSC principles.

- $\quad$ To apply critical thinking.

- $\quad$ To work effectively in a team.

- $\quad$ To communicate effectively, both verbally and in writing.

Proctor Plumbing Limited is an outstanding organisation. It is dedicated towards achieving the highest possible standards for its customers, employees and owners: "exceeding every expectation" is the firm's motto. Dan Wallace, the CEO recently attended a training session on the Balanced Scorecard (BSC). He is of the view that the BSC is something that could be used to enhance the performance of Proctor Plumbing, as little formal performance measurement exists. He decided to introduce the technique during the coming year.

The company has been in existence for many years, distributing quality niche products to the New Zealand plumbing and drainage industry. Among the company's products are high-quality bathroom fittings, top of the line plumbing products and high-tech equipment for water supply and drainage. Products are sourced from independent

1 This case study is adapted from a case written by William Cotton Under the terms of an exclusive Memorandum of Understanding between Advanced Business Education Limited and a real New Zealand company. The name and details of the company have been changed at the request of the management. However the situations and material described in the case reflect the real company. Copyright Advanced Business Education Limited 2005 -reproduced with permission 
companies world-wide, including New Zealand. Over the previous three years there has been a concerted effort to broaden the range of product available, as market research indicated customers wanted quality and innovation through new technology. Proctor Plumbing is serious about the effectiveness of its team of employees. It has a "results driven" structure that is flat, with all people valued equally within the organisation. Proctor Plumbing is highly visible in the marketplace, supporting industry events through trade display attendance, marketing initiative and networking with a team of experienced sales engineers and product managers committed to visiting key accounts on a regular basis. Proctor Plumbing Limited has the following core values: success, innovation and leadership.

\section{TEACHING NOTES}

\section{Required: In teams}

- $\quad$ Reach agreement on goals for Proctor Plumbing Limited.

- $\quad$ Establish appropriate measures for Proctor Plumbing Limited.

- $\quad$ Produce the wall poster illustration of the BSC for Proctor Plumbing Limited.

- $\quad$ Take a wall poster illustration gallery tour which requires: (1) all teams rotate the room reviewing each wall poster illustration and (2) teams assess the content and presentation of the illustration (details of assessment criteria are detailed below).

- $\quad$ Stand, Move and Chat (SMAC). All members of teams STAND, look across the room, and find someone to approach to talk about the goals and measures. Students MOVE to the person they have identified and then CHAT about the results.

\section{Case Commentary}

Proctor Plumbing Limited: BSC Suggested Template

\begin{tabular}{|l|l|l|l|}
\hline \multicolumn{1}{|c|}{ Goals } & \multicolumn{1}{c|}{ Measures } & \multicolumn{1}{c|}{ Goals } \\
\hline \multicolumn{1}{|c|}{ Measures } \\
\hline Cash Flow & Actual/Budget & Customer acquisition & Prospect calls \\
\hline Net Profit & Actual/Budget & Customer profitability & Net value each \\
\hline Operating Expenses & Actual/Budget & Customer retention & Lost business \\
\hline Revenue Growth & $\%$ achieved & Customer satisfaction & Survey \\
\hline Revenue-New Markets & $\%$ achieved & Management visibility & Key account calls \\
\hline Return on Equity Internal Process & Rep Visibility & Call rates \\
\hline \multicolumn{1}{|c|}{ Measures } & \multicolumn{1}{c|}{ Goals } & \multicolumn{1}{c|}{ Measures } \\
\hline \multicolumn{2}{|c|}{ Goals } & \multicolumn{1}{c|}{ Empowerment } & Improvement suggestions \\
\hline Bar coding & No of product groups & Information access & $\%$ staff with access \\
\hline Correct product portfolio & Stock turns & Key Staff retention & Staff turnover \\
\hline Employee numbers & Revenue per employee & \% of total revenue \\
\hline Excellence in performance & KPI Appraisals quarterly & New products & Aligned goal setting quarterly \\
\hline Inventory management & Stock outs & Staff Involvement & Annual survey \\
\hline Lead time & Delivery & Team work & \$ Actual/Budget \\
\hline
\end{tabular}

\section{Suggested Assessment Criteria: BSC Wall Poster Illustration}

\section{Presentation criteria}

- $\quad$ Four sections in order of Financial, Customer, Internal Process, and Learning and Growth.

- $\quad$ Separate columns for goals and measures in the four categories.

- $\quad$ Effective visual - include writing neatness. 


\section{Content criteria}

- $\quad$ Listed appropriate goals in all four sections of the balanced scorecard.

- $\quad$ Supported the goals with appropriate measures.

\section{REFERENCES}

1. Blundell, B., Sayers, H., and Y.P. Shanahan (2003). The Balanced Scorecard in New Zealand: A Survey of the Top 40, Pacific Accounting Review, 15, 1, 49-74.

2. Kaplan, R.S. and D.P. Norton (1992). The Balanced Scorecard - Measures that Drive Performance, Harvard Business Review, January-February, 71-79.

3. Kaplan, R. S. and Norton, D. P. (2001a). Transforming the balanced scorecard from performance measurement to strategic management: part I. Accounting Horizons, 15, 1 87-104.

4. Kaplan, R. S. and Norton, D. P. (2001b). Transforming the balanced scorecard from performance measurement to strategic management: part II, Accounting Horizons, 15, 2, 147-160.

\section{NOTES}

